\title{
The impact of new production technology on employee productivity in the South African workplace
}

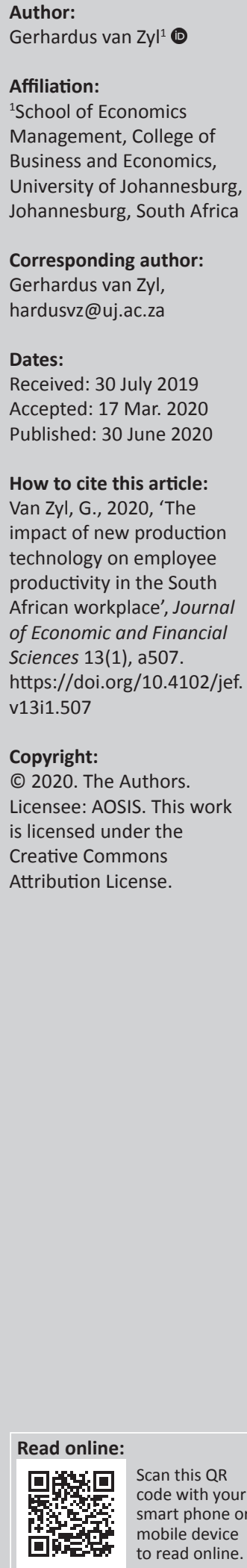

Orientation: This study is part of an ongoing research project on various aspects of employee productivity in the South African workplace.

Research purpose: The aim of this article was to determine the firm-based employee productivity impacts because of the acquisition and introduction of new production technologies in the South African workplace.

Motivation for the study: The study focusses on understanding the impact of various components of new production technology on employee productivity for different age groups and skill levels.

Research approach/design and method: The study adopts two distinct estimation processes. The aim of the first set of estimations was to construct a technology index. Secondly, fixedpanel data estimations determine the percentage change in employee productivity based on technology-to-employee ratio, technology index, different technology components, different age groups and different skill levels. The manufacturing industry of Gauteng is the focus of this case study.

Main findings: Estimation results indicate, in general, positive employee productivity effects, superior employee productivity gains for the 35- to 55-year employee age group and greater employee productivity gains for the lower-skilled employee segment.

Practical/managerial implications: The estimation rankings of new production technology for the improvement of employee productivity, are of the utmost importance when deciding on the acquisition and introduction of different kinds of new production technologies in the workplace.

Contribution/value-add: The study contributes to our understanding on how the acquisition of new production technologies could affect employee productivity at the workplace.

Keywords: technology; fixed-panel data estimations; components of new technology; employee productivity; International Standard Classification of Occupations (IOCO-88); manufacturing industry.

\section{Introduction}

The aim of this article was to determine the firm-based employee productivity impacts as a result of acquisition and implementation of new production technologies in the South African workplace.

The rapid change in the technology base of firm activities and the impact it has on employee productivity is an important aspect in the debate on employee productivity. No published firmbased research findings are available on the technology-employee productivity link for the South African workplace. This study specifically focusses on generating firm-based estimation results of the technology-employee productivity relationship when new machines and equipment technologies and employee diversity aggregates, such as age and skill levels, are included in the estimations.

The article is part of an ongoing research project on various aspects of employee productivity in the South African workplace. Research thus far has covered various aspects of firm-based employee productivity. These are (1) remuneration dispersion (Van Zyl 2010); (2) different ageskill categories (Van Zyl 2013a); (3) qualifications (Van Zyl 2013b); (4) employee diversity (Van Zyl 2014); (5) incentive schemes (Van Zyl 2015); (6) non-unionised participation platforms (Van Zyl 2016); (7) in-house training (Van Zyl 2017) and (8) employee migration to smaller firms (Van Zyl 2019). 


\section{Literature study}

The impact of technological innovations on employee productivity at the industry level has been well researched globally (Allmon et al. 2000; Altamirano \& De Beers 2017; Antonioli, Mazzanti \& Pini 2010; Brynjolfsson \& Hitt 2003; Conti 2005; Filipetti \& Peyrache 2015; Goodrum \& Haas 2004; Johangard 2008; Kunt \& Kunt 2015; Lim \& Sanidas 2011; Macičiulyte-Sniukiene \& Gaile-Sarkane 2014; Mamum \& Wickremasinghe2014; Olinder\&Sichel2002;Papakonstantinou 2014; Romer 2006; Sharpe \& Qiao 2006; Techolz 2001). The estimation results of these studies (on the technologyemployee productivity relationship) are mainly based on published data sets, and estimation results based on firmbased data are limited. The literature indicates that, in general, technological innovations (in whatever format) have a positive impact on employee productivity. There are three main streams of literature on the impact of technology innovation on employee productivity.

The first stream of literature focusses specifically on the impact of information and communication technological innovations (hereafter referred to as ICT innovation) on employee productivity. Aspects that are generally covered include the diffusion of ICT innovations (transmission mechanisms) and the removal of workplace inefficiencies and intensity levels of ICT technologies. Kunt and Kunt (2015) concluded that ICT innovation affects employee productivity via a transmission mechanism (accelerated workflow $\rightarrow$ increased efficiency of production processes $\rightarrow$ employee productivity) and that higher skilled employees create higher levels of productivity when ICT innovation is introduced in the workplace. The study by MacičiulyteSniukiene and Gaile-Sarkane (2014) argued that ICT innovation creates effective dissemination of information and via improved administrative and human resource strategies affects employee productivity positively. Romer (2006) was of the opinion that ICT technology innovations are responsible for the removal of inefficiencies in the workplace, thus contributing to higher levels of employee productivity. Mamum and Wickremasinghe (2014) were of the opinion that ICT innovation removes information asymmetry in the workplace, thus allowing employees to perform their duties more productively. Short-run diffusion of ICT innovation is faster than long-run diffusion. The argument is that workplace imperfections are removed more quickly and could translate sooner into higher employee productivity levels. The studies conducted by Johangard (2008) and Olinder and Sichel (2002) have concluded that low levels of ICT innovation result in suboptimal capital-to-labour ratios (and ultimately in weaker employee productivity levels) and that the employee productivity effect of ICT innovations is smaller for developing economies, compared to developed economies.

The second stream of literature focusses, in addition to ICT innovation, on the impact of both organisational innovations (hereafter referred to as OI) and technological innovations (hereafter referred to as TI) on employee productivity. Two major aspects covered in this literature stream include the importance of complementary innovations to ICT and different OI channels. Brynjolfsson and Hitt (2003) and Antonioli et al. (2010) argued that OI, such as supply chain management improvements, innovative training practices and improved human resource management, and product innovations for both products and services, should complement ICT innovation in the workplace and result in greater levels of employee productivity. The study conducted by Papakonstantinou (2014) concluded that complementary innovations to ICT innovation create a greater level of skilled employees, with a resultant positive impact on employee productivity. Conti (2005) was of the opinion that the generation and accumulation of skill levels are complementary to technology innovations and that only under these circumstances can diffusion of organisational innovations and technological innovations occur to have a positive effect on employee productivity.

The third stream of literature deals in depth with the impact of production technology innovation (new machinery and equipment) on employee productivity. This stream of research covers aspects such as different driving factors of technological innovations in machinery and equipment, cost of new production technologies, different types of technologies and creation of competitive advantages as a result of investment in new production technologies. Lim and Sanidas (2011) argued that the effect of technical production innovations on employee productivity differs between firms and industries. This study indicates the importance of capital-to-employee ratio to capture the capital intensity of new production technologies. The study performed by Altamirano and De Beers (2017) concluded that technological innovations in the production of capital stock significantly improves employee productivity and that new production technology innovations achieve competitive advantages for firms and industries. Increased employee productivity is an important channel for the attainment of a competitive edge in the market. Sharpe and Qiao (2006) considered the cost of investing in new production technologies. The high real cost of new production technologies could dampen investment in new machinery and equipment, with a resultant limited impact on the improvement of employee productivity. The study conducted by Goodrum and Hass (2004) was a major contribution to understanding the impact of technological innovation in machinery and equipment in the workplace on employee productivity. The study argued that acquisition and implementation of new machine and equipment technologies will result in relative increase in capital-to-employee ratios, and thus ultimately affect employee productivity positively. There are five distinct driving factors for the relative increase in the capital-to-employee ratio, namely, the level of amplification of human energy, the level of control, the fundamental range, ergonomics and information processing. All of these driving forces must be included in determining the effect of production technology innovations on employee productivity. 
It is important to note that new technologies (in whatever form) will partly explain improvements in employee productivity and that there are other factors such as improvement in human capital and learning-by-doing effects that would also affect employee productivity. This study focusses mainly on the impact of new production technology innovations on employee productivity in the South African workplace.

\section{Research design \\ Research approach and method}

The research design comprises the following:

- Specification of the technology-employee productivity estimation model

- Identification of firm-based technology index factors, construction of a firm-based technology index and firmbased technology-employee ratios

- Identification of age and skill-level attributes to be included in the technology-employee productivity estimation model

- Compilation of firm-based data sets

- Different estimation processes

- Interpretation of estimation results

\section{Data requirements}

The manufacturing industry of Gauteng Province is used as a case study to capture the employee productivity effects because of the acquisition and implementation of new production technologies (given the importance of this industry in the gross geographical product of Gauteng Province and the availability of firm-based data). Individual firms in the sample group supplied firm-based data. The sample set of 74 firms covers a variety of sub-sectors in the manufacturing industry. The sample set of firms is statistically significant.

The sample period is 2009-2016, and the collation of the required data covers biannual time periods (2009-2010; 20112012; 2013-2014; and 2015-2016). For each firm in the sample, the following required data sets apply for each year of the sample period:

- Real production monetary values

- Real employee remuneration values

- Real spending on machinery and equipment

- Real expenditure on new ICT infrastructure

- Real spending on new machinery and equipment

- Lists to rate the importance of technology-driving factors (in order to calculate technology index scores)

- Total employees according to three age groups and two skill levels. In order to maintain continuity in the broader research agenda on various aspects of firm-based employee productivity in the South African workplace, the same descriptors for age and skill levels are used. The following three age groups are used: younger than 35 years, between 35 and 55 years of age and older than 55 years of age. The International Standard Classification of
Occupations (IOCO-88) is used to distinguish between skilled occupations (Category A) and less skilled occupations (Category B) (Van Zyl 2017).

\section{Model specification}

The estimation of change in employee productivity is on a biannual basis (2009 and 2010; 2011 and 2012; 2013 and 2014; and 2015 and 2016).

Distinct estimation processes are applied in this article. For the first set of estimations, an adapted version of the Goodrum and Haas (2004) model is applied. The aim of these estimations was to construct a technology index and technology-to-employee ratios. This is executed for each firm over biannual time periods to estimate percentage changes in employee productivity.

In the model, real average expenditure on machinery and equipment is the proxy for technology. Real average remuneration levels of employees are the proxies for the employee component in the technology-to-employee ratio. Estimating changes in employee productivity requires the construction of a technology index. The technology index is the sum of index score changes of the impact factors of technology divided by the number of observations (Equation 1):

Technology index $=\Sigma^{N}{ }_{i, t}(\Delta \mathrm{FR}+\Delta \mathrm{EE}+\Delta \mathrm{ER}+\Delta \mathrm{EC}+\Delta \mathrm{IP}) \div N$.

[Eqn 1]

In Equation 1:

- $\Delta \mathrm{FR}$ is the changes in the index scores of the functional range of equipment and machinery for firm $i$ for period $t$.

- $\Delta \mathrm{EE}$ is the changes in the index scores of employee effort in the workplace for firm $i$ for period $t$.

- $\quad \Delta \mathrm{ER}$ is the changes in the index scores of ergonomic characteristics of equipment and machinery for firm $i$ for period $t$.

- $\triangle \mathrm{EC}$ is the changes in the index scores of physical employee control over machinery and equipment for firm $i$ for period $t$.

- $\Delta \mathrm{IP}$ is the changes in the index scores of information processing in the workplace for firm $i$ for period $t$.

- $\quad N$ is the number of observations.

The quantification of the level of change of each of these technology impact factors (because of real changes in machinery and equipment spending) is performed in the following manner:

For no changes, a value of 0 is awarded; for limited changes, a value of 1 is awarded; for medium-level changes, a value of 2 is awarded, and for high-level changes, a value of 3 is awarded. A technology index score for each firm in the sample is determined for biannual time periods. In this model, employee productivity is the real production value divided by the total real employee remuneration. 
The percentage change in employee productivity (for each firm over biannual time periods) is defined according to Equation 2:

$\%$ change in $\mathrm{EP}=\mathrm{EP}$ year $_{x}-\mathrm{EP}_{\text {year }}{ }_{x-1} \div \mathrm{EP}_{x-1}$

In Equation 2:

- EP is employee productivity

- Year is the current year

- Year $_{x-1}$ is the previous year

A biannual employee-productivity-compound-rate for each firm in the sample is calculated.

The existence of collinearity between different technology impact factors is considered once the technology index is constructed.

The next step is to construct changes to the technology-toemployee ratio (for each firm over biannual time periods). Changes in technology-to-employee ratio are defined according to Equation 3:

$\Delta$ technology-to-employee ratio $=\left(\mathrm{TE}_{\mathrm{x}} / \mathrm{EM}_{\mathrm{x}}\right)-\left(\mathrm{TE}_{\mathrm{x}-1} / \mathrm{EM}_{\mathrm{x}-1}\right)$

[Eqn 3]

In Equation 3:

- $\mathrm{TE}_{x}$ is the current real average expenditure on technology

- $\mathrm{EM}_{x}$ is the current real average employee remuneration level

- $\mathrm{TE}_{x-1}$ is the real average expenditure on technology in the previous period

- $\mathrm{EM}_{x-1}$ is the real average employee remuneration level in the previous period

A higher technology-to-employee ratio is indicative of greater technology intensity levels.

The next step is to perform a simplified regression for the relationship between changes in the technology-to-employee ratio and employee productivity for the sample of firms over biannual time periods. Positive estimates are indicative of positive relationships between the real expenditure on production technology and employee productivity. Increase in employee productivity is thus linked to increase in the technology-to-employee ratio (improvement in production technology facilitates real increase in employee productivity). The magnitude of estimates is also considered. Higher positive estimate values are indicative of higher positive effects on employee productivity, whilst lower positive estimate values are indicative of lesser effects on employee productivity.

The next step is the estimation of the relationship between technology index, technology-to-employee ratio and changes in employee productivity for the sample of firms:
$\% \Delta$ in employee productivity $=f$ (technology index, technologyto-employee ratio).

[Eqn 4]

A quadratic regression for this particular relationship is performed for different biannual time periods. Of importance for this study are the sign and magnitude of estimations and the average variance of changes in employee productivity. The regression estimates indicate the percentage change in employee productivity, which is attributed to changes in technology index and technology-to-employee ratio. Higher values of technology index and technology-toemployee ratios would result in a higher positive percentage change in employee productivity. The opposite is also true.

The next step is to cater for the impact of individual technology factors on employee productivity. To perform estimations, a series of dummy variables are included (a value of 1 if a change in technology is experienced, and a value of 0 if no change in technology is experienced). This is performed for the samples of firms for biannual time periods. The aim of these estimations was to determine the magnitude of impact that each technology component has on changes in employee productivity.

For the second set of estimations, fixed-panel data estimations are performed wherein employee diversity attributes of age and skill levels are included (for the entire sample of firms over biannual time periods). Fixed-panel data estimations are performed to determine the percentage change in employee productivity based on technology-to-employee ratio, technology index, different technology components, different age groups and different skill levels. These fixedpanel estimations are performed for different biannual timeperiods. In the fixed-panel data estimations, employee productivity is defined as the percentage change in real average production divided by average real employee remuneration. The percentage change in employee productivity is calculated according to Equation 5:

$\% \Delta \mathrm{EP}_{i, t, t-1}=\alpha \Delta \mathrm{TE}^{-\mathrm{EM}_{i, t, t-1}}+\beta \mathrm{TI}_{i, t, t-1}+\lambda \mathrm{ICT}_{i, t, t-1}+\theta \Sigma \mathrm{n}_{i, t, t-1}\left(\Delta \mathrm{FR}_{a, s}\right.$

$\left.+\Delta \mathrm{EE}_{a, s}+\Delta \mathrm{ER}_{a, s}+\Delta \mathrm{EC}_{a, s}+\Delta \mathrm{IP}_{a, s}\right)+\varepsilon$.

In Equation 5:

- $\% \Delta \mathrm{EP}_{i, t, t-1}$ is the percentage change in employee productivity for firm $i$ for the period $t-(t-1)$.

- $\alpha \Delta$ TE-EM $\mathrm{E}_{i, t,-1}$ is the real technology-employee ratio for firm $i$ for the period $t-(t-1)$.

- $\quad \beta \mathrm{TI}_{i, t, t-1}$ is the technology index for firm $i$ for the period $t-(t-1)$.

- $\quad \lambda \mathrm{ICT}_{i, t,-1}$ is real ICT spending for firm $i$ for the period $t-(t-1)$.

- $\theta \sum n_{i, t, t-1}$ is the sum of technology factors for different age groups and different skill levels for firm $i$ for the period $t-(t-1)$.

- $\Delta \mathrm{FR}_{a, s}$ is the change in the functional range of different age groups and skill levels.

- $\Delta \mathrm{EE}_{a, s}$ is the change in employee effort because of improvement in technology for different age groups and skill levels. 
- $\Delta \mathrm{ER}_{a, s}$ is the change in ergonomic characteristics for different age groups and skill levels.

- $\Delta \mathrm{EC}_{a, s}$ is the change in physical employee control over equipment and machinery for different age groups and skill levels.

- $\Delta \mathrm{IP}_{a, s}$ is the change in information processing in the workplace for different age groups and skill levels.

- $\varepsilon$ is the error term.

The fixed-panel data estimates are indicative of the percentage impact of each technology component on employee productivity for each age group and skill level over biannual time periods for the sample group of firms. A positive estimate relates to an increase in employee productivity, whilst a negative estimate indicates a decrease in employee productivity.

\section{Estimation results}

The first estimation relates to the percentage annual growth in employee productivity (defined as percentage growth in real production values divided by the percentage increase in real employee remuneration) because of real spending on new technology for the full sample of firms over the 2009-2016 time period.

The estimation results indicate that employee productivity grew by $16.2 \%$ over this period at an average biannual rate of $4.05 \%$. These results are indicative of the positive effect that growth in real spending on new machinery and equipment has on employee productivity. The results also confirm greater percentage growth rates for employee productivity during the biannual time periods in which real spending on new production technologies accelerated.

The second estimation results relate to the possible existence of collinearity between different technology impact factors. The aim was to make sure that standard errors do not increase in the panel data estimations (for the sample group of firms). A correlation matrix for technology index components is constructed (Figure 1).

The highest level of pair-wise collinearity is between the change in employee effort and the change in the physical employee control over new machinery and equipment. The lowest level of pair-wise collinearity is between the change in the physical control over new machinery and equipment and the change in the ergonomic characteristics of new machinery and equipment. The matrix indicates no collinearity, given the fact that no pair-wise correlation exceeds a maximum benchmark of 0.70 . This result confirms the significance of each of the technology components and the technology index per se.

The third estimation results consider the regression results of the effects of technology index and technology-to-employee ratio on the percentage change in employee productivity for the full sample group of firms (Figure 2).
Of importance is the magnitude and expansion of $R^{2}$. The results indicate that for the whole sample of firms, on average $31 \%$ of increase in employee productivity is explained by changes in technology index and technology-to-employee ratio. It is also important to note that this trend has constantly increased over biannual time periods.

The fourth regression results on employee productivity also cater to technology-change versus no-technology-change scenario for the full sample of firms. A dummy variable series is included in the regression to cater for these scenarios. The aim of this particular regression was to estimate the percentage of total variation in employee productivity as well as the employee productivity contribution of different technology components because of different driving factors of technology changes, technology impact scenarios and technology-toemployee ratio. The regression results are listed in Figure 3.

Changes in different components of technology, technology index, technology-to-employee ratio and different technology scenarios explain $32 \%$ of increase in employee productivity. This result is similar to the previous regression result. In terms of the impact of different technology components on employee productivity, the results indicate (for full sample of firms) that changes in the ergonomic characteristics of new machinery and equipment have the highest positive impact on employee productivity (they contribute $18 \%$ of increase in employee productivity). The functional range of new equipment and machinery has the lowest positive impact on employee productivity (about $4.5 \%$ ).

\begin{tabular}{lccccc}
\hline & $\mathrm{TI}_{\mathrm{FR}}$ & $\mathrm{TI}_{\mathrm{EE}}$ & $\mathrm{TI}_{\mathrm{ER}}$ & $\mathrm{TI}_{\mathrm{EC}}$ & $\mathrm{T}_{\mathrm{IP}}$ \\
\hline $\mathrm{TI}_{\mathrm{FR}}$ & 1 & 0.36 & 0.35 & 0.17 & 0.22 \\
$\mathrm{TI}_{\mathrm{EE}}$ & 0.36 & 1 & 0.40 & 0.41 & 0.33 \\
$\mathrm{TI}_{\mathrm{ER}}$ & 0.35 & 0.40 & 1 & 0.01 & 0.35 \\
$\mathrm{TI}_{\mathrm{EC}}$ & 0.17 & 0.41 & 0.01 & 1 & 0.05 \\
$\mathrm{~T}_{\mathrm{IP}}$ & 0.22 & 0.33 & 0.35 & 0.05 & 1 \\
\hline
\end{tabular}

Note: All correlations are significant at the $95 \%$ confidence level.

FIGURE 1: Correlation matrix for technology index components.

\begin{tabular}{lcccc}
\hline Bi-annual time-period & Constant & $(\mathrm{T} / \mathrm{E})^{2}$ & $\mathrm{Tl}^{2}$ & $\mathbf{R}^{2}$ \\
\hline 2009-2010 & 2.64 & $\begin{array}{c}88.24 \\
(3.14)\end{array}$ & $\begin{array}{c}7.12 \\
(4.02)\end{array}$ & 0.28 \\
& & $\begin{array}{c}89.92 \\
(2.88)\end{array}$ & $\begin{array}{c}7.88 \\
(3.78)\end{array}$ & 0.29 \\
$2010-2012$ & 2.89 & 92.18 & 8.12 & 0.32 \\
$2013-2014$ & 3.12 & $(2.90)$ & $(3.04)$ & \\
& & 93.52 & 8.64 & 0.33 \\
$2015-2016$ & 3.48 & $(3.08)$ & $(4.16)$ & \\
\hline
\end{tabular}

Note: The $t$-values are in parenthesis. $\mathrm{N}=74$.

FIGURE 2: Percentage change in employee productivity.

\begin{tabular}{lcccccccc}
\hline Constant & T/E & TI & FR & EE & ER & EC & IP & $\mathbf{R}^{2}$ \\
\hline 3.43 & 82.48 & 10.12 & 4.48 & 15.43 & 18.10 & 12.12 & 2.02 & 0.32 \\
$(0.12)$ & $(3.44)$ & $(2.14)$ & $(1.88)$ & $(4.62)$ & $(3.88)$ & $(3.25)$ & $(1.08)$ & \\
\hline
\end{tabular}

Note: The $t$-values are in parenthesis.

$\mathrm{T} / \mathrm{E}$, technology-to-employee ratio; $\mathrm{Tl}$, technological innovations; $F \mathrm{R}$, functional range; $\mathrm{EE}$, employee effort; ER, ergonomic characteristics; EC, employee control; IP, information processing.

FIGURE 3: Percentage change in employee productivity. 
The results of fixed-panel data estimations are listed in Figures 4-7.

$\alpha_{\mathrm{T} / \mathrm{EM}}:$ The positive technology-employee estimates are an indication that the percentage growth in the real spending on new technology compared to the percentage growth in real employee remuneration (technology-employee ratio increase) had a continuous positive impact on employee productivity over biannual time periods.

$\beta_{\mathrm{TI}}$ : An increase in technology index has a continuous positive impact on employee productivity. Increased real spending on new machinery and equipment over biannual time periods created greater positive index values for technology components, and thus an increasing positive impact on employee productivity.

$\lambda_{\mathrm{ICT}}$ : The positive estimation for ICT indicates a positive relationship between real spending on ICT and employee productivity. This is true for all biannual time periods.

Expansion in the functional range of new machinery and equipment has a positive percentage growth impact on

\begin{tabular}{lcccc}
\hline & $\mathbf{2 0 0 9 - 2 0 1 0}$ & $\mathbf{2 0 1 1 - 2 0 1 2}$ & $\mathbf{2 0 1 3 - 2 0 1 4}$ & $\mathbf{2 0 1 5 - 2 0 1 6}$ \\
\hline$\alpha_{\text {T/EM }}$ & 5.11 & 5.78 & 6.03 & 6.08 \\
& $(1.88)$ & $(2.01)$ & $(1.78)$ & $(2.42)$ \\
$\beta_{\text {TI }}$ & 4.04 & 4.09 & 5.11 & 5.29 \\
& $(1.64)$ & $(2.19)$ & $(2.06)$ & $(2.18)$ \\
$\lambda_{\text {ICT }}$ & 3.27 & 3.33 & 3.59 & 3.77 \\
& $(1.13)$ & $(1.09)$ & $(1.23)$ & $(1.31)$ \\
\hline
\end{tabular}

Note: The $t$-values are in parenthesis.

$\alpha_{T / E M^{\prime}}$ technology-employee ratio; $\beta_{T I^{\prime}}$ technology index; $\lambda_{\mathrm{ICT}}$, ICT spending.

FIGURE 4: Summary of panel data estimations: Technology-employee ratio and technology index.

\begin{tabular}{|c|c|c|c|c|}
\hline & 2009-2010 & 2011-2012 & 2013-2014 & 2015-2016 \\
\hline$\theta_{\Delta F \text { Ra below } 35}$ & $\begin{array}{c}5.14 \\
(1.65)\end{array}$ & $\begin{array}{c}5.37 \\
(2.17)\end{array}$ & $\begin{array}{c}5.54 \\
(1.89)\end{array}$ & $\begin{array}{c}5.63 \\
(2.55)\end{array}$ \\
\hline$\theta_{\Delta \mathrm{FRa} 35-55}$ & $\begin{array}{c}6.05 \\
(2.23)\end{array}$ & $\begin{array}{c}6.19 \\
(1.76)\end{array}$ & $\begin{array}{c}6.27 \\
(2.75)\end{array}$ & $\begin{array}{c}6.51 \\
(3.03)\end{array}$ \\
\hline$\theta_{\Delta F R a \text { older } 55}$ & $\begin{array}{c}2.10 \\
(1.76)\end{array}$ & $\begin{array}{c}2.13 \\
(1.21)\end{array}$ & $\begin{array}{c}2.17 \\
(1.74)\end{array}$ & $\begin{array}{c}2.20 \\
(1.82)\end{array}$ \\
\hline$\theta_{\Delta \text { FRa category A }}$ & $\begin{array}{c}3.17 \\
(1.88)\end{array}$ & $\begin{array}{c}3.21 \\
(1.65)\end{array}$ & $\begin{array}{c}3.46 \\
(1.68)\end{array}$ & $\begin{array}{c}3.68 \\
(1.08)\end{array}$ \\
\hline$\theta_{\Delta F R a \text { category B }}$ & $\begin{array}{c}5.06 \\
(2.07)\end{array}$ & $\begin{array}{c}5.81 \\
(1.99)\end{array}$ & $\begin{array}{c}6.09 \\
(2.69)\end{array}$ & $\begin{array}{c}6.17 \\
(2.32)\end{array}$ \\
\hline
\end{tabular}

Note: The $t$-values are in parenthesis.

FR, functional range.

FIGURE 5: Summary of panel data estimations: The functional range of new technology.

\begin{tabular}{|c|c|c|c|c|}
\hline & 2009-2010 & 2011-2012 & 2013-2014 & 2015-2016 \\
\hline$\theta_{\Delta \text { EEa below } 35}$ & $\begin{array}{c}2.11 \\
(1.01)\end{array}$ & $\begin{array}{c}2.15 \\
(1.03)\end{array}$ & $\begin{array}{c}2.21 \\
(1.08)\end{array}$ & $\begin{array}{c}2.29 \\
(1.05)\end{array}$ \\
\hline$\theta_{\Delta \mathrm{EEa} 35-55}$ & $\begin{array}{c}5.01 \\
(2.16)\end{array}$ & $\begin{array}{c}5.07 \\
(2.05)\end{array}$ & $\begin{array}{c}5.34 \\
(1.88)\end{array}$ & $\begin{array}{c}5.37 \\
(2.17)\end{array}$ \\
\hline$\theta_{\Delta \text { EEa older } 55}$ & $\begin{array}{c}4.13 \\
(1.16)\end{array}$ & $\begin{array}{c}4.17 \\
(1.21)\end{array}$ & $\begin{array}{c}4.51 \\
(1.71)\end{array}$ & $\begin{array}{c}4.77 \\
(1.08)\end{array}$ \\
\hline$\theta_{\Delta \text { EEa category A }}$ & $\begin{array}{c}3.04 \\
(1.53)\end{array}$ & $\begin{array}{c}3.14 \\
(1.66)\end{array}$ & $\begin{array}{c}3.23 \\
(2.07)\end{array}$ & $\begin{array}{c}3.31 \\
(1.97)\end{array}$ \\
\hline$\theta_{\Delta E \text { Ea category B }}$ & $\begin{array}{c}4.11 \\
(1.59)\end{array}$ & $\begin{array}{c}4.19 \\
(1.77)\end{array}$ & $\begin{array}{c}4.53 \\
(1.59)\end{array}$ & $\begin{array}{c}4 \\
(1.55)\end{array}$ \\
\hline
\end{tabular}

Note: The $t$-values are in parenthesis.

$\mathrm{EE}$, employee effort.

FIGURE 6: Summary of panel data estimations: Employee effort of new technology.

\begin{tabular}{|c|c|c|c|c|}
\hline & 2009-2010 & 2011-2012 & 2013-2014 & 2015-2016 \\
\hline$\theta_{\Delta \text { ERa below } 35}$ & $\begin{array}{c}3.11 \\
(1.78)\end{array}$ & $\begin{array}{c}3.21 \\
(1.65)\end{array}$ & $\begin{array}{c}3.27 \\
(1.71)\end{array}$ & $\begin{array}{c}3.51 \\
(1.80)\end{array}$ \\
\hline$\theta_{\Delta E R a ~ 35-55}$ & $\begin{array}{c}5.71 \\
(2.18)\end{array}$ & $\begin{array}{c}5.83 \\
(2.08)\end{array}$ & $\begin{array}{c}6.04 \\
(2.88)\end{array}$ & $\begin{array}{c}6.12 \\
(2.68)\end{array}$ \\
\hline$\theta_{\Delta E R a \text { older } 55}$ & $\begin{array}{c}5.93 \\
(1.98)\end{array}$ & $\begin{array}{c}6.07 \\
(2.18)\end{array}$ & $\begin{array}{c}6.19 \\
(2.38)\end{array}$ & $\begin{array}{c}6.37 \\
(2.17)\end{array}$ \\
\hline$\theta_{\Delta \text { ERa category A }}$ & $\begin{array}{c}4.04 \\
(1.48)\end{array}$ & $\begin{array}{c}4.17 \\
(1.33)\end{array}$ & $\begin{array}{c}4.23 \\
(1.27)\end{array}$ & $\begin{array}{c}4.31 \\
(1.62)\end{array}$ \\
\hline$\theta_{\Delta E \text { Ra category B }}$ & $\begin{array}{c}3.27 \\
(2.01)\end{array}$ & $\begin{array}{c}3.31 \\
(1.85)\end{array}$ & $\begin{array}{c}3.41 \\
(1.97)\end{array}$ & $\begin{array}{c}3.53 \\
(2.03)\end{array}$ \\
\hline
\end{tabular}

Note: The $t$-values are in parenthesis.

ER, ergonomic characteristics.

FIGURE 7: Summary of panel data estimations: Ergonomic characteristics.

employee productivity for all age groups and different skill levels. The positive percentage growth impact is more pertinent for the 35-55 age group and for the lower-skilled (category B) employee category. The least positive productivity growth impact is for employees in the older age group and for the higher-skilled employee category.

The employee effort impact of new technology has a positive impact on employee productivity for all age groups and skill levels (Figure 6). The positive impact is more pertinent for the 35-55 employee age group and for the lower-skilled category of employees. The employee effort impact of new technology is much lower for the youngest segment of employees and for the more-skilled employee category.

The improved ergonomic characteristics of new technology have a positive impact on employee productivity for all age groups and skill levels (Figure 7). Employees in the oldest age group and the higher-skilled employee category experience the highest increase in employee productivity. Employees in the youngest age group and the lower-skilled employee category experience the lowest increase in employee productivity.

Changes in the physical control over new machinery and equipment (less human control) have a positive impact on employee productivity for all employee age groups and skill levels (Figure 8). These higher employee productivity impacts are pertinent for the 35-55 employee age group and for the lower-skilled employee category. The employee productivity impacts are the lowest for the younger employee age group and for the higher-skilled employee segment.

Changes in the information-processing capabilities of new machinery and equipment have a positive impact on employee productivity for all employee age groups and skill levels (Figure 9). These higher employee productivity impacts are pertinent for the older than 55 years age group and for higher-skilled employees. The employee productivity impacts are the lowest for the younger employee age group and the lower-skilled employee category.

The estimation results, in general, indicate that the highest positive employee productivity impact of the expansion of new technology is generated by the 35-55 years age group (three of the five components of technology) and by the lower-skilled employee segment (four of the five components of technology). 


\begin{tabular}{|c|c|c|c|c|}
\hline & 2009-2010 & 2011-2012 & 2013-2014 & 2015-2016 \\
\hline$\theta_{\Delta \mathrm{ECa} \text { below } 35}$ & $\begin{array}{c}2.91 \\
(1.11)\end{array}$ & $\begin{array}{c}3.01 \\
(1.44)\end{array}$ & $\begin{array}{c}3.11 \\
(1.69)\end{array}$ & $\begin{array}{c}3.16 \\
(1.62)\end{array}$ \\
\hline$\theta_{\triangle \mathrm{\triangle EC} 35-55}$ & $\begin{array}{c}4.91 \\
(1.99)\end{array}$ & $\begin{array}{c}5.08 \\
(2.11)\end{array}$ & $\begin{array}{c}5.16 \\
(2.13)\end{array}$ & $\begin{array}{c}5.22 \\
(2.17)\end{array}$ \\
\hline$\theta_{\Delta E C \text { o older } 55}$ & $\begin{array}{c}4.72 \\
(1.91)\end{array}$ & $\begin{array}{c}4.84 \\
2.06)\end{array}$ & $\begin{array}{c}4.02 \\
(1.89)\end{array}$ & $\begin{array}{c}5.03 \\
(2.29)\end{array}$ \\
\hline$\theta_{\triangle E C \text { a category } A}$ & $\begin{array}{c}2.14 \\
(1.31)\end{array}$ & $\begin{array}{c}2.35 \\
(1.18)\end{array}$ & $\begin{array}{c}2.47 \\
(1.19)\end{array}$ & $\begin{array}{c}2.61 \\
(1.61)\end{array}$ \\
\hline$\theta_{\Delta E \text { Ca category B }}$ & $\begin{array}{c}3.76 \\
(1.09)\end{array}$ & $\begin{array}{c}3.84 \\
(1.05)\end{array}$ & $\begin{array}{c}4.04 \\
(1.07)\end{array}$ & $\begin{array}{c}4.13 \\
(1.16)\end{array}$ \\
\hline
\end{tabular}

Note: The $t$-values are in parenthesis.

$\mathrm{EC}$, employee control.

FIGURE 8: Summary of panel data estimations: Change in employee physical control.

\begin{tabular}{|c|c|c|c|c|}
\hline & 2009-2010 & 2011-2012 & 2013-2014 & 2015-2016 \\
\hline$\theta_{\Delta \mathrm{IPa} \text { below } 35}$ & $\begin{array}{c}1.85 \\
(0.81)\end{array}$ & $\begin{array}{c}2.03 \\
(0.76)\end{array}$ & $\begin{array}{c}2.08 \\
(0.49)\end{array}$ & $\begin{array}{c}2.14 \\
(0.62)\end{array}$ \\
\hline$\theta_{\triangle 1 \mathrm{~Pa} 35-55}$ & $\begin{array}{c}2.54 \\
(1.02)\end{array}$ & $\begin{array}{c}2.59 \\
(0.99)\end{array}$ & $\begin{array}{c}2.61 \\
(1.05)\end{array}$ & $\begin{array}{c}2.67 \\
(1.01)\end{array}$ \\
\hline$\theta_{\Delta \mid \mathrm{Pa} \text { older } 55}$ & $\begin{array}{c}3.02 \\
(1.11)\end{array}$ & $\begin{array}{c}3.07 \\
(1.02)\end{array}$ & $\begin{array}{c}3.14 \\
(1.08)\end{array}$ & $\begin{array}{c}3.20 \\
(1.13)\end{array}$ \\
\hline$\theta_{\Delta \mathbb{P} \text { a category A }}$ & $\begin{array}{c}2.34 \\
(1.05)\end{array}$ & $\begin{array}{c}2.41 \\
(1.01)\end{array}$ & $\begin{array}{c}2.49 \\
(1.05)\end{array}$ & $\begin{array}{c}2.51 \\
(1.09)\end{array}$ \\
\hline$\theta_{\Delta I P a \text { category B }}$ & $\begin{array}{c}1.67 \\
(0.69)\end{array}$ & $\begin{array}{c}1.76 \\
(0.75)\end{array}$ & $\begin{array}{c}1.79 \\
(0.67)\end{array}$ & $\begin{array}{c}1.83 \\
(0.76)\end{array}$ \\
\hline
\end{tabular}

Note: The $t$-values are in parenthesis.

IP, information processing.

FIGURE 9: Summary of panel data estimations: Change in information processing.

\section{Conclusion}

The aim of this article was to determine the firm-based employee productivity impacts because of the acquisition and introduction of new production technology in the South African workplace.

The results of this study, firstly, confirm international research results that improvements in the technology base of firms, in general, has a positive impact on employee productivity. Secondly, the results of this study indicate variable positive employee productivity impacts that an improvement in production technology (through an increase in the functional range of new technology, lower employee effort, improved ergonomic characteristics of new technology, less physical employee control over new technology and higher levels in information processing) has on different employee age groups and skill levels in the workplace. Thirdly, the estimation results again confirm, in general, the higher employee productivity levels generated by the 35-55 employee age group as concluded in previous studies (Van Zyl 2016, 2017). In contrast with the findings of previous studies on other aspects of firm-based employee productivity, the lower-skilled employee segment, in general, generated greater employee productivity levels because of the acquisition and implementation of new production technology.

This study could be developed further by way of a comparative examination of the impact of technology on employee productivity between different industries. In addition, more employee diversity parameters, such as gender and race, could be included in the future studies.

\section{Acknowledgements Competing interests}

The author has declared that no competing interests exist.

\section{Authors' contributions}

The author declares that he is the sole author of this research article.

\section{Ethical consideration}

This article followed all ethical standards for a research without direct contact with human or animal subjects.

\section{Funding information}

This research received no specific grant from any funding agency in the public, commercial or not-for-profit sectors.

\section{Data availability statement}

Data sharing is not applicable to this article as no new data were created or analysed in this study.

\section{Disclaimer}

The views and opinions expressed in this article are those of the author and do not necessarily reflect the official policy or position of any affiliated agency of the author.

\section{References}

Allmon, E., Haas, C., Borcherding, J. \& Goodrum, P., 2000, 'US construction labor productivity trends, 1970-1998', Journal of Construction Engineering and Management 126(2), 97-104. https://doi.org/10.1061/(ASCE)0733-9364(2000) 126:2(97)

Altamirano, M.A. \& De Beers, C.P., 2017, 'Frugal innovations in technological and institutional infrastructure: Impact of mobile phone technology on productivity, public service provision and inclusiveness', The European Journal of Development Research 30(1), 84-107. https://doi.org/10.1057/s41287-017-0115-2

Antonioli, D., Mazzanti, M. \& Pini, P., 2010, 'Productivity, innovation strategies and industrial relations in SMEs: Empirical evidence for a local production system in Northern Italy', International Review of Applied Economics 24(4), 453-482. https://doi.org/10.1080/02692171.2010.483790

Brynjolfsson, E. \& Hitt, L.M., 2003, 'Computing productivity: Firm level evidence', Review of Economics and Statistics 85(4), 793-808. https://doi.org/10.2139/ ssrn. 290325

Conti, G., 2005, 'Training, productivity and wages in Italy', Labour Economics 12(4), 557-576. https://doi.org/10.1016/j.labeco.2005.05.007

Filipetti, A. \& Peyrache, A., 2015, 'Technology or investment? An enquiry into the Chinese model of growth at the region level', Innovation and Development 5(1), 39-58. https://doi.org/10.1080/2157930X.2014.1003449

Goodrum, P.M. \& Haas, C.T., 2004, 'Long-term impact of equipment technology on labor productivity in the US construction industry at the activity level', Journal of Construction Engineering and Management 130(1), 124-133. https://doi. org/10.1061/(ASCE)0733-9364(2004)130:1(124)

Johangard, E., 2008, ICT impact on the labor productivity in the Iranian manufacturing industries: A multi-level analysis, viewed 03 April 2019, from https://papers.ssrn. com/so/3/papers.cfm.

Kunt, S. \& Kunt, Ü., 2015, 'Innovation and labour productivity in BRICS countries: Pane causality and co-integration', Procedia-Social and Behavioral Sciences 195(2015), 1295-1302. https://doi.org/10.1016/j.sbspro.2015.06.296

Lim, J. \& Sanidas, E., 2011, 'The impact of organisational and technical innovations on productivity: The case of Korean firms and sectors', Asian Journal of Technology Innovation 19(1), 21-35. https://doi.org/10.1080/19761597.2011.578432

Macičiulyte-Sniukiene, A. \& Gaile-Sarkane, E., 2014, 'Impact of information and telecommunication technologies development on labour productivity', ProcediaSocial and Behavioral Sciences 110(2014), 1271-1282. https://doi.org/10.1016/j. sbspro.2013.12.974 
Mamum, M.A. \& Wickremasinghe, G.B., 2014, Dynamic linkages between diffusion of information communication technology and labour productivity in South Asia', Applied Economics 46(26), 3246-3260. https://doi.org/10.1080/00036846.2014 Applied Ecor
927573

Olinder, S.D. \& Sichel, D.E., 2002, 'Information technology and productivity: Where are we now and where are we going?' Federal Reserve Bank of Atlanta Economic Review 87(Q3), 15-44.

Papakonstantinou, M., 2014, 'Composition of human capital, distance to the frontier and productivity, Paper Prepared for the IARIW 33Rd General Conference, Rotterdam, August 24-30, 2014.

Romer, D., 2006, Advanced macroeconomics, McGraw Hill, New York.

Sharpe, A \& Qiao, S., 2006, 'The role of labor market information for adjustment: International comparison, Centre for Study of Living Standard (CSLS) research report', Skilled research initiative working paper No 2006-c 14, social science and humanities research council, Ottawa.

Techolz, P., 2001, 'Discussion of US construction labor productivity trends, 1970-1998', Journal of Construction Engineering Management 127(5), 427-428.

Van Zyl, G., 2010, 'Does employee remuneration dispersion in the South African economy enhance labour productivity? The Gauteng manufacturing industry as a case study', South African Journal of Human Resource Management 8(1), 1-5. https://doi.org/10.4102/sajhrm.v8i1.286
Van Zyl, G., 2013a, 'Relative labour productivity contribution of different age-skill categories for a developing economy: The Gauteng province of South Africa as a case study', South African Journal of Human Resource Management 11(1), 1-8. https://doi.org/10.4102/sajhrm.v11i1.472

Van Zyl, G., 2013b, 'Positive labour productivity externalities that arises from a postsecondary qualification or training', Journal of Economic \& Financial Sciences 6(3), 761-777.

Van Zyl, G., 2014, 'Labour productivity and employee diversity in the South African workplace', Journal of Economic \& Financial Sciences 7(2), 451-466.

Van Zyl, G., 2015, 'Impact of incentive schemes on employee productivity in the South African workplace', Journal of Economic \& Financial Sciences 8(2), 633-647. https://doi.org/10.4102/jef.v8i2.113

Van Zyl, G., 2016, 'Impact of non-unionised participation platforms on employee productivity in the South African workplace', Journal of Economic \& Financia Sciences 9(1), 93-105. https://doi.org/10.4102/jef.v9i1.31

Van Zyl, G., 2017, 'Impact of in-house training on employee productivity in the South African workplace', Journal of Economic \& Financial Sciences 10(1), 160-175.

Van Zyl, G., 2019, 'Employee diversity attributes of productivity and real remuneration spillover impacts of employee migration to smaller firms in the South African workplace', Journal of Economic and Financial Sciences 12(1), 1-8. https://doi. org/10.4102/jef.v12i1.203 